\title{
Isolation and Identification of Bacteria Responsible for the Spoilage of Fluted Pumpkin (Telfaria occidentalis) and Bitter Leaf (Vernonia amygdalina) in Sokoto Metropolis
}

\author{
'A.S. Muhammad* \\ Department of Crop Science, \\ Usmanu Danfodiyo University Sokoto
}

\author{
${ }_{2}^{2}$ S.A. Ani \\ Department of Crop Science, \\ Usmanu Danfodiyo University Sokoto
}

\author{
${ }^{3}$ A.M. Nasiru \\ ${ }^{3}$ Department of Forestry and Environment, \\ Usmanu Danfodiyo University Sokoto
}

Article DOI: https://doi.org/10.36713/epra4997

\begin{abstract}
The research was conducted in 2016 at the Microbiology Laboratory in the Department of Microbiology in Usmanu Danfodiyo University Sokoto. The main objective was to isolate and identify those bacteria responsible for the spoilage of bitter leaf (Vernonia amygdalina) and fluted pumpkin (Telfairia occidentalis). This approach presented extracting these bacteria form the vegetables and then culture then on agar plates, colonies were formed and subcultures on different plates, pure cultures were obtained and cultured in slant bottles containing nutrient agar for identification through biochemical test bacterial utilization of substrates which include Triple sugar ion, Methyl red and Vogues prosturer test, starch hydrolysis, Indole, citrate, catalase, urease test and recorded. Gram stain was carried out to identify the gram reaction and viewed under microscope for cell morphology. Bacteria species of the stock culture were identified using Atlas Book of Bacteria using the biochemical test results and gram stain reactions, the bacteria isolated were identified as gram negative rod bacteria. Percentage distribution of occurrence showed that $E$. coli had had the highest frequency of occurrence with percentage distribution of $42.8 \%$ in bitter leaf, followed by Proteus mirabilis, and B. cereus both having $28.6 \%$ respectively. Proteus mirabilis had $50 \%$ in fluted pumpkin, Klebsiella 33.3\%, E. coli 16.7\%. From the result, it was concluded that E. coli and Proteus had the highest occurrence of bacterial contamination of spoilt bitter leaf and fluted pumpkin sold in Sokoto metropolis and recommended sensitization proper hygienic measure during post-harvest handling of these vegetables.
\end{abstract}

KEYWORDS: Isolation, Identification, Bacteria, Vegetables, Food Spoilage, Hygiene

\section{INTRODUCTION}

Vegetables are among the major dietary intake in our everyday life. They are succulent herbaceous plants that are eaten in parts, whole, raw or cooked as a part of our main dish or in salad. They are characterized by high moisture content being of the order of $75 \%$ moisture or more and $25 \%$ or less dry matter. Leafy vegetables are an important feature of Nigeria diet that a traditional meal without it is assumed to be incomplete. In developing countries, the consumption of vegetables is generally lower than the FAO (2004) recommended of $75 \mathrm{Kg}$ per year in habitat (206g per day per capita) (Badmus and Yekini, 2011).

One of the factors that impacts negatively on the economic value of vegetables is that they have a short shelf life. This is a result of many factors, prominent among which is the activity of pathogens. It has been reported (Droby, 2006) that about 20-25\% of 
harvested vegetables are lost through the activities of pathogens during the post-harvest chain. Growing vegetables may be exposed to many sources of contamination this include microbes through contact with soil, dust and water by handling harvest. This makes them to harbor a wide range of microorganisms including both plant and human pathogens (Eni et al., 2010).

In developing countries such as Nigeria continued use of untreated waste water and manure as fertilizer for the production of vegetables is a major contributing factor. Effect of the microbial activities of these vegetables has resulted in an increase in disease spread. Also generally supplements of vitamins and minerals gotten from these vegetables have been reduced drastically, losses of farmers' income are pronounced, loss of vegetables is on the rise, vegetables not fresh are hardly consumed also malnutrition generally is encouraged. All these are detrimental to the inhabitants of these locations and also affect Nigeria at large, stretching its negativity affecting the economy of the nation as a whole.

These vegetables are being sold into our homes, offices, restaurants, canteen, on the street where we buy our suya, in our markets and our neighborhoods. Providing an increasing chance of disease infection, malnutrition, vitamin deficiency in children and adults, vegetables spoilages dump on the street polluting the environments but the key bacteriology safe vegetables are essential to maximize the health benefit promised by adequate consumption of good and clean vegetables. Proper washing of fruit and vegetables is essential for decontamination and safe consumption of these products as they are eaten mostly raw or minimally cooked.

Therefore, the objective of this study is:

To isolate and identify the major bacteria species associated with the spoilage of bitter leaf (Vernonia amygdalina) and fluted pumpkin (Telfairia occidentalis) in Sokoto Metropolis.

\section{MATERIALS AND METHODS Study Area}

The study was conducted in 2016 at the Microbiology Laboratory in the Department of Microbiology in Usmanu Danfodiyo University Sokoto. Sokoto metropolis comprises Sokoto North, Sokoto South Local Government and some part of Kware and Wamako Local Government Area and located at $13.08^{\circ} \mathrm{N}, 5.250^{\circ} \mathrm{E}$ of the equator. It is located in the extreme Northwest of Nigeria, near the confluence of Sokoto River and Rima River and falls within the Sudan Savannah ecological zone. It is populated with vicarious categories of people, some of which are peasant farmers, traders and artisans. The dominant ethnic group is Hausa. As of the 2006 national population census, it has a population of 427 , 760.

\section{Samples Collection}

Two species of vegetables were randomly purchased for three different markets in Sokoto metropolis; the samples include only spoiled vegetables. The vegetables are fluted pumpkin (ugwu, Kabewa (Telfairia occidentalis)), Bitter leaf (onugbu, efo, shuawaka (Vernonia amygdalina)). These vegetables were collected into different sterile, labelled polythene bags and transported to the Microbiology Laboratory, in the Department of Microbiology Usmanu Danfodiyo University, Sokoto immediately after collection for processing.

\section{Materials and Reagents}

The materials and reagents used in the laboratory investigation include; spoiled vegetables, microscope, distilled water, nutrient agar, saline, Petri dishes, test tubes, pipettes, and Gram staining reagents etc.

\section{Materials Sterilization}

All the glassware were properly washed, dried and sterilized in the oven at $160^{\circ} \mathrm{C}$ for one hour and were allowed to cool down to room temperature before utilization. The entire working surfaces were also disinfected with ethanol to reduce contaminants.

\section{Nutrient Agar}

Nutrient Agar was used as a basal media for bacterial culture. It was prepared according to the manufacturer's instructions. $28 \mathrm{~g}$ of the dehydrated powder was weighed and dissolved in 1000mls (1 litre) of distilled water inside a conical flask. It was corked with cotton wool and covered with aluminum foil and heated to dissolve the agar. The suspension was then autoclaved at $121^{\circ} \mathrm{C}$ for 15 minutes; it was left to cool down at room temperature for another 15 minutes before dispensing. $20 \mathrm{mls}$ of the prepared media was dispensed into Petri dishes.

\section{TSA Preparation}

Nutrient Agar was used as a basal media for bacterial culture. It was prepared according to the manufacturer's instructions. $38 \mathrm{~g}$ of the dehydrated powder was weighed and dissolved in $1000 \mathrm{mls}$ (1 litre) of distilled water inside a conical flask. It was corked with cotton wool and covered with aluminum foil and heated to dissolve the agar. The suspension was then autoclaved at $121^{\circ} \mathrm{C}$ for 15 minutes; it was left to cool down at room temperature for another 15 minutes before dispensing. $20 \mathrm{mls}$ of the prepared media was dispensed into Petri dishes 


\section{Isolation and Identification of Bacteria}

The spoilt vegetables were soaked and serial dilution was carried out by weighing $1 \mathrm{~g}$ of the sample in $10 \mathrm{ml}$ of distilled water. The samples were left to soak for 10 minutes before transferring $1 \mathrm{ml}$ of the diluents into another $9 \mathrm{ml}$ of distilled water. The transfer of the $1 \mathrm{ml}$ continues until it reaches $10^{5}$ diluents. $0.1 \mathrm{ml}$ was withdrawn from the last diluents using $5 \mathrm{ml}$ syringe and placed in a triplicate plate of TSA. Sterile glass rod was then used to spread the inoculums of the suspension on the entire surface of the TSA plate. The inoculated plates were incubated at $37^{\circ} \mathrm{C}$ for 24 hours.

Emerging colonies on the plates were counted and counted as colony forming units per millilitre $(\mathrm{CFU} / \mathrm{ml})$. Some of the distinct colonies will be subcultured severally until pure cultures are obtained. The pure cultures were subjected to gram staining, catalase and oxidase tests.

\section{Gram Stain}

A smear of the bacterial cell was made on a slide and stained, using the Gram stain procedure. The slides were thereafter viewed under the microscope for the presence of gram positive bacterial cells. A drop of distilled water was placed on a grease fire glass slide and a colony in the nutrient agar plate was picked with a heated wire loop (after allowing it to cool) and emulsified. The glass slide was passed through flame three times to heat fix. The smear was flooded with crystal violet for 30 seconds and rinsed with distilled water. Lugol's iodine then was added to the smear for 30 seconds and then rinsed with distilled water. The smear was counterstained with safranin for 1-2 minutes and rinsed with distilled water. After air dried, oil immersions were added and viewed under microscopic using x100 objective lens. The isolates were identified and confirmed with the morphological characteristic (Cheesbrough, 2000).

\section{Urease Test}

This test was to detect the organism's ability to produce enzyme urease that hydrolysis urea into ammonia and carbon dioxide. With the release of ammonia the pale yellow of urea changes to pink-red, this signified the positive for urea. Colony from the stock culture was sub-cultured into nutrient agar to obtain a fresh culture. Heavy inoculums were fetched from the nutrient agar using sterile wire loop and streaked on the slant surface of the urea medium. It was incubated for 24 hours at $37^{\circ} \mathrm{C}$. The development of a pink-red signifies the presence of urease, if the color remained unchanged (yellow or orange) it signifies negative (Cheesbrough, 2000).

\section{Indole Test}

This test was used in the determination of the ability of bacteria to produce indole from tryptophan. Indole production is detected by Kovac's reagent, which contains 4(p)-dimethylaminobenzaldehyde. The reaction of the reagent with indole produces a red colored compound. The isolates were grown for 48 hours in a test tube containing $5 \mathrm{ml}$ peptone water; $0.5 \mathrm{ml}$ Kovac's reagent was added and shaken gently. The presence of a red or pink layer indicated the presence of indole while absence of red color indicates negative (Cheesbrough, 2000).

\section{Citrate Test}

This was one of the several techniques used to assist in the identification of some bacteria. The test is based on the ability of an organism to use citrate as its source of carbon. Simmon citrate agar was inoculated with the isolate and incubated at $37^{\circ} \mathrm{C}$ for 48 hours. The presence of a bright blue color indicated positive for citrate while a bright blue color indicates negative (Cheesbrough, 2000).

\section{Catalase Test}

This test was used to differentiate those bacteria that produce the enzyme catalase from non-catalase producing ones. Catalase acts as a catalyst in the breakdown of hydrogen peroxide to oxygen and water. A drop of hydrogen peroxide was placed on a clean slide, colonies from the nutrient slant which was fetched and emulsified in the $\mathrm{H}_{2} \mathrm{O}_{2}$ and observed immediately for gas bubbles. The presence of active bubbles indicates positive for catalase while no bubbles indicates negative for catalase (Cheesbrough, 2000).

\section{Methyl Red and Voges Proskauer Test}

This test was used to differentiate bacteria that ferment glucose with the production of acetyl methyl acetate (acetone). The media contains peptone salt and glucose. Colonies from the stock culture were inoculated into methyl red medium and incubated at $37^{\circ} \mathrm{C}$ for 48 hours. 2 drops of a methyl red solution were added and shaken. The presence of a red color indicates positive while a yellow color indicates negative (Cheesbrough, 2000).

\section{Triple Sugar Iron Agar Test}

This medium contains three sugars; glucose, sucrose and lactose. Some organisms can ferment all the three sugars present and produce acid which changes the color of the indicator from red to yellow. The sugar and protein were attacked oxidatively to release ammonia. Through this media, the production of $\mathrm{H}_{2} \mathrm{~S}$ can be detected by the presence of a black color in the media along the area being stabbed by the wire 
loop. Gas production can be detected by the presence of gas bubbles or cracks on the agar in the test tube or complete disruption of the medium. Colonies from the sub-cultured plate were picked with a sterile straight wire loop and stabbed on the cut, streaked on the surface of the slope. This was incubated at $37^{\circ} \mathrm{C}$ for 24 hours (Cheesbrough, 2000).

\section{Starch Hydrolysis}

This test shows whether an isolate is capable of utilizing starch or not. Each isolate will be inoculated into a starch hydrolysis medium (nutrient agar + starch) and incubated for 24 hours. After incubation, iodine solution will be added to each growth and blue black color was observed. Development of blue black indicates the presence of starch, that is, the isolate could not utilize starch and so by failure to develop blue black coloration indicates a positive for starch utilizing bacteria (Cheesbrough, 2000).

\section{RESULTS}

\section{Frequency Bacterial Contamination of Bitter leaf and fluted pumpkin}

A total of three species of bacteria were isolated from the sample of fluted pumpkin used. These bacteria were identified as Klebsiella, Proteus mirabilis and E. coli as shown in Table 1. From the table, out of the six (6) bacteria isolated, P. mirabilis presented the highest frequency of occurrence with the percentage occurrence of $50 \%$. $33.3 \%$ was also recorded for Klebsiella while $E$. coli had the least frequency of occurrence with a percentage of $16.7 \%$.

Table: Percentage Distribution of Organisms identified in Fluted Pumpkin

\begin{tabular}{|l|c|c|c|}
\hline S/N & Organisms Identified & No of Occurrences & Percentage Occurrence (\%) \\
\hline 1. & Klebsiella & 2 & 33.3 \\
\hline 2. & P. mirabilis & 3 & 50 \\
\hline 3. & E. coli & 1 & 16.7 \\
\hline & Total & $\mathbf{6}$ & $\mathbf{1 0 0}$ \\
\hline
\end{tabular}

\section{Frequency Bacterial Contamination of Bitter Leaf}

A total of seven (7) bacteria belonging to three species of bacteria were isolated and identified from the bitter leaf used in the present investigation. These species include Proteus mirabilis, E. coli and B. cereus.
Out of the bacteria isolated, the highest frequency of occurrence was noted for $E$. coli with a percentage occurrence of $42.8 \%$. Both $P$. mirabilis and $B$. cereus had percentages of $28.5 \%$ and $28.6 \%$ respectively as shown in Table 2.

Table: Percentage Distribution of Organisms identified in Bitter Leaf

\begin{tabular}{|c|c|c|c|}
\hline S/N & Organisms Identified & No of Occurrences & Percentage Occurrence (\%) \\
\hline 1. & P. mirabilis & 2 & 28.6 \\
\hline 2. & E. coli & 3 & 42.8 \\
\hline 3. & B. cereus & 2 & 28.6 \\
\hline & Total & $\mathbf{7}$ & $\mathbf{1 0 0}$ \\
\hline
\end{tabular}

The comparison between the fluted pumpkin and bitter leaf in relation to the bacterial isolate is presented in chart 1. From the chart, P. mirabilis was observed to have the highest frequency of occurrence in the fluted pumpkin while the highest percentage occurrence for the bitter leaf was recorded for the $E$. coli. All the bacteria isolated were found in both the bitter leaf and fluted pumpkin except for $B$. cereus which was absent in fluted pumpkin and Klebsiella which was also absent in bitter leaf. 


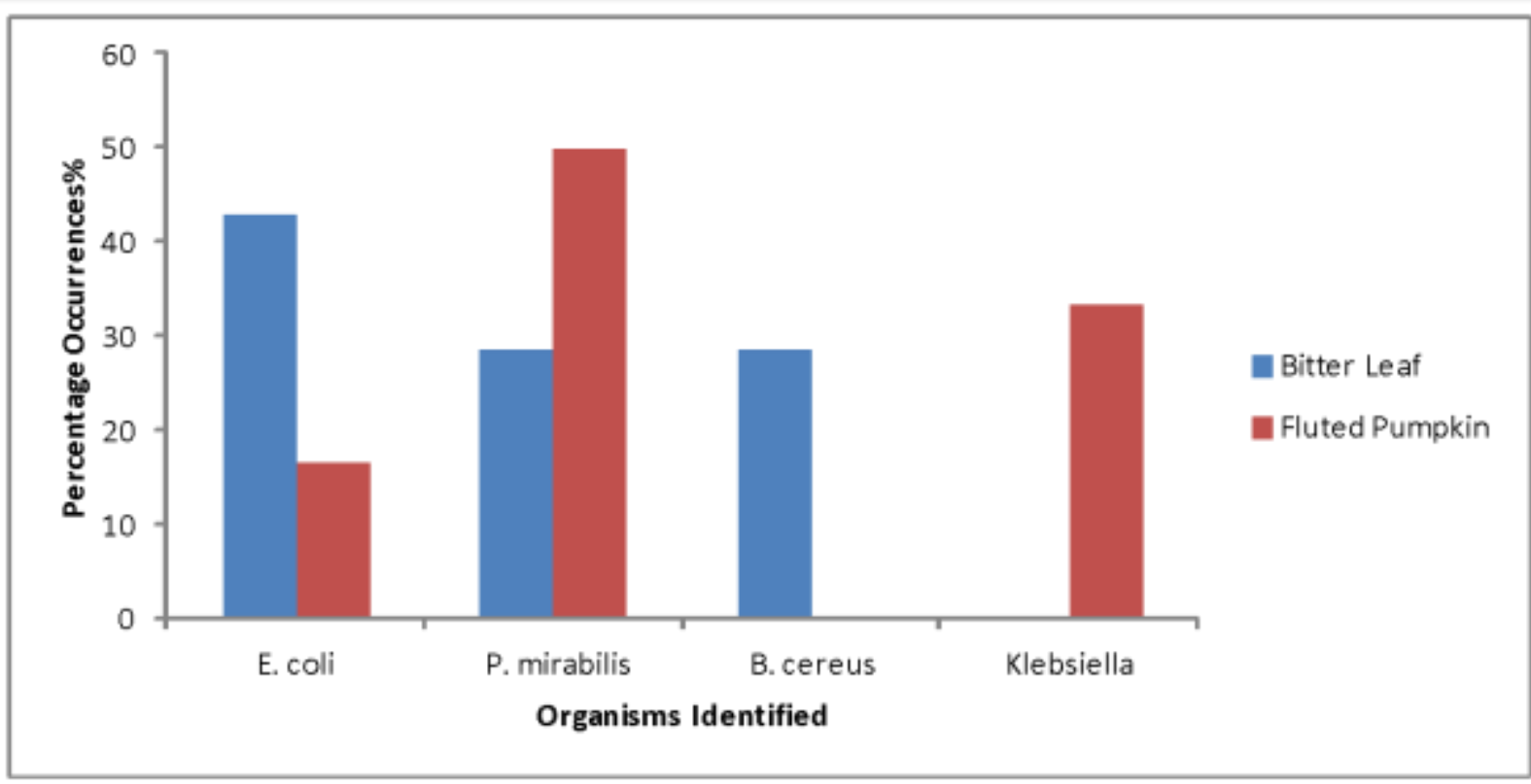

Figure 1: Species of Bacteria Isolated from Bitter Leaf and Fluted Pumpkin in Sokoto Metropolis.

\section{DISCUSSION, CONCLUSION AND RECOMMENDATIONS Discussion}

Fresh vegetables fruits including bitter leaf and fluted pumpkin have naturally effective immunity against most pathogenic microorganisms and plant spoilage. But this protection or immunity however could be hindered and eventually leading to the contamination of these vegetables. There are several factors that promote the contamination and post-harvest deterioration of vegetables by bacteria; these include contamination during field cultivation, harvesting, postharvest handling and distribution (Beuchat, 2002). The result of the isolation and identification of bacteria presented in table 1 and 2 revealed that bacteria were the major organisms responsible for the post-harvest spoilage of both bitter leaf and fluted pumpkin. From the present study, both the bitter leaf and the fluted pumpkin had the same number of bacterial isolates, with the highest frequency of occurrence from bitter leaf and fluted pumpkin observed to be $42.8 \%$ and $50 \%$ respectively. This result is in line with the observation of (Mathew, 2011) who reported that bacteria were the major sources of contamination and post-harvest spoilage of vegetables.

Earlier works such as Chuku et al. (2008) isolated various strains of bacteria from vegetables and observed Bacillus megaterium and Bacillus laterosporus as the major contaminants and agents of post-harvest deterioration of vegetables. Other work like the works of (Chuku et al., 2008; Ofor et al., 2009; Okafo, 1997) found that Bacillus subtilis, B. cereus, $B$. aureu, Lactobacillus fermenti, Pseudomonas stutzeri, Leuconostoc spp and Rothia spp. As well as fungi $A$. flavus, $A$. fumigates, Penicillium expansum, $P$. notatum, E. coli, Mucor mucedo, Monilia spp, Klebsiella from vegetables. Similar report was observed in sweet orange fruit damage (Tafinta et al., 2013).

Figure I indicate that between the bitter leaf and fluted pumpkin samples collected from Sokoto metropolis, $P$. mirabilis had the highest frequency of occurrence $(50 \%)$ for the fluted pumpkin followed by $42.8 \%$ for the bitter leaf. This indicated that fluted pumpkin sold in Sokoto metropolis market had the higher cases of microbial contamination when compared with the bitter leaf.

\section{CONCLUSION}

The research showed that bacteria are still a health problem among vegetable consumers in Sokoto metropolis, the presence of the bacteria isolated from both bitter leaf and fluted pumpkin could pose a serious threat to the health of consumers of these vegetables as they are pathogenic and are harmful when consumed. It has been identified by recent study that some independent variables that demonstrated significant correlation with bacterial infection are personal hygiene, environment hygiene, consumption of unhygienic vegetables, age, gender and use of contaminated manure and water to plants. The study therefore concludes that a proper personal and environmental hygiene, washing and proper cooking of 
these vegetables will greatly reduce the population density of the bacteria.

\section{Recommendations}

There is a serious need for sensitization on good personal and environmental hygiene as means of preventing the persistence of bacterial contamination of vegetables in developing countries. This should be achieved through proper education, treatment of manure before application, especially faecal manure, proper washing and cooking of root vegetables before consumption.

\section{REFERENCES}

1. Akoroda, M. O. and Adejoro, M. A. (1989). Patterns of vegetative and sexual development of Telfairia occidentalis Hook. $f$. Tropical Agriculture (Trinidad) 67(3): 243-247.

2. Akwaowo, E. U., Ndon, D. A. and Etuk, E. U. (2000). Minerals and antinutrients in fluted pumpkin (Telfairia occidentalis Hook. f.). Food Chemistry 70(2): 235-240.

3. Awor, A. M. (2005). Post-harvest handling of indigenous fruits and vegetables: status, problems and prospects. Paper presented at the Meeting of Experts on Indigenous Crops and Animal Research and Development, Nigeria.

4. Badmus, M. A. and Yekinni, O. T. (2011). "Economic Analysis of Exotic Vegetable Production among Urban Fadama Women Farmers in Akinyele Local Government Area Oyo State, Nigeria". International Journal of Agricultural Economics and Rural development 4 (1) 2011

5. Beuchat L. R. (2002). Ecological factors influencing survival and growth of human pathogens on raw fruits and vegetables. Microbes and Infection, 4: 413-423.

6. Bezabih, S. N. and Hadera, N. (2007). Activity of four plant extracts against three fungal pathogens of rice. Trop. Agric.(Trinidad). 68. Pp 373 - 375

7. Booth, R. H. (1974). Postharvest Deterioration of Tropical Root Crops: losses and their control. Journal of Tropical Science. 16:49-63.

8. Burkill, H. M. (1985). The useful plants of West Tropical Africa. 2nd Edition. Volume 1, Families A-D. Royal Botanic Gardens, Kew, Richmond, United Kingdom. 960 pp.

9. Byezynski, S. L. (1997). "Growing for Market", Handbook of crop storage, Vol. 1 No, pp. 4-5.

10. Cheesebrough, M. J. (2000). Medical laboratory manual for tropical countries, Microbiology. Tropical Health Technology and Butterworth Scientific Publication, 11:167-214.

11. Chuku, E. C., Ogbonna, D. N., Onuegbu, B. A. and Adeleke, M. T. V. (2008). Comparative studies on the fungi and biochemical characteristics of snake gourd (Trichosanthes cucumerina linn) and Tomato (Lycopersicon esculentum Mill) in River
State, Nigeria.

8(1): 168-172.

12. Dhanze, H., Khurana, S. K. and Mane, B. G. (2013). Effect of seabuckthorn leaf extract on microbiological quality of raw chicken during extended periods of storage. Journal of Food Quality, 36(1): 59-66.

13. Droby, S. (2006). Improving quality and Safety of Fresh Fruits and Vegetables After Harvest by the use of Biocontrol Agents and Natural Materials. Acta Horticul. 709: 45-51.

14. Egbekan, M. K., Nda-Suleiman, E. O. and Akinyeye, O. (1998). Utilization of fluted pumpkin fruit (Telfairia occidentalis) in marmalade manufacturing. Plant Foods for Human Nutrition 52(2): $171-176$.

15. Ellah, O. C. (2004): Toxin in pathogenesis. Annual Review of Phytopathology. (18): 103-129.

16. Eni, A. O., Oluwawemitan, T. O. and Solomon, $O$. U. (2010). Microbial Quality of Fruits and Vegetables Sold in Sango Ota, Ogun State, Nigeria. African Journal of Food Science, 4(5): 291-296.

17. F.A.O. (2004). "Food Loss Prevention in Perishable Crops", Corporate Document Repository, pp. 220-231.

18. FAO/WHO: Report of a Joint FAO/WHO Expert Consultation Bangkok, Thailand (2008). Expert consultationon human vitamin and mineral requirements. pp. 223-229.

19. Fejokwu, J. O. (1992). Report of the nationally coordinated research project on fruits and vegetables in Nigeria. Proc.Nat. Workshop on Improved Packaging and Storage Systems for Fruits and Vegetables in Nigeria. Ilorin, Nigeria.

20. George, C., Gavini, F., Vaugien, L., Butel, M. J. and Doucet-Popularie, F. (2010). Antimicrobial susceptibility of Bifidobacteria. Journal of Antimicrobial Chemotherapy, 55:38-44.

21. Ghebremeskel, A. N. (2007). A model to predict damage to horticultural produce during transport. Journalof Agricultural Engineering Research 50: 259-72.

22. Harris, J. C., Cottrell, S. L., Plummer, S. and Lloyd, D. (2003). Antimicrobial properties of Allium sativum(garlic). Applied Microbiology and Biotechnology, 57:282-286.

23. Maliku, J. M. (2005), "Reduction of losses in fresh market fruits and vegetables", Annual review of phytopathology, Vol. 16 No. 1, pp. 321-341.

24. Mashav (2010). "Postharvest Losses of Fruits and Vegetables”,Availableat:http//www.mashav.mfa.Do cument ID=42327 (Viewed March, 2012).

25. Mathew, F. A. (2011). "Handbook of Fruits and Vegetables", National publishers, Ibadan.

26. Mofeke, F., Clavin, M. L., Weber, D., Ranea, F., Anke, T. and Martino, V. (2005). Antimicrobial isoflavonoids from Erythrina crista galli infected with Phomopsis sp. Z. Naturforsch. $\quad 62(3-4)$ : 164-168.

27. Obiagwu, C. J. and Odiaka, N. I. (1995). Fertilizer schedule for yield of fresh fluted pumpkin (Telfairia 
ISSN (Online): 2455-3662

EPRA International Journal of Multidisciplinary Research (IJMR) - Peer Reviewed Journal

Volume: 7 | Issue: 1 |January 2021|| Journal DOI: 10.36713/epra2013 || SJIF Impact Factor: 7.032||ISI Value: 1.188

occidentalis) grown in the lower Benue river basin of Nigeria. Indian Journal of Agricultural Sciences, 65(2): $98-101$

28. Odiaka, N. I. (2001). Survey on the production and supply of Telfairia occidentalis in Makurdi, Benue State Nigeria. Crop Production Department, University of Agriculture, Makurdi, Nigeria.

29. Ofor, M. O, Okorie, V. C., Ibeawuchi, I. I., Ihejirika, G. O, Obilo, O. P, and Dialoke, S. A. (2009). Microbial Contaminants in Fresh Tomato Wash Water and Food Safety Considerations in South-Eastern Nigeria. Life Science Journal, 1:8082.

30. Okafor, J.C., (1997). Conservation and use of traditional vegetables from woody forest species in southeastern Nigeria. In: Guarino, L. (Editor). Traditional African vegetables. Proceedings of the IPGRI international workshop on genetic resources of traditional vegetables in Africa: conservation and use, 29-31 August 1995, ICRAF, Nairobi, Kenya. Promoting the conservation and use of underutilized and neglected crops 16. pp. 31-38.

31. Oke, O. L. (1973). Leaf protein research in Nigeria. Tropical Science 15: 139-155.

32. Okigbo, R. N. (2009). Variation in phytochemical properties of selected fungicidal aqueous extract of some plant leaves in Kogi State, Nigeria. American European Journal of Sustainable Agriculture, 3 (3): 407- 409

33. Olaofe, O., Adeyemi, F. O. and Adediran, G. O. (1994). Amino acid and mineral compositions and functional properties of some oilseeds. Journal of Agricultural and Food Chemistry, 42(4): 878881.

34. Prakash, A., Mathur, K., Vishwakarma, A., Vuppu, S. and Mishr, B. (2013). Comparative assay of antioxidant and antibacterial properties of Indian culinary seasonal fruit peel extracts obtained from Vellore, Tamilnadu. International Journal of Pharmaceutical Sciences Review and Research, 19(1): 131-135.

35. Ray, J. M. and Bhuria, R. E. (2007). "The commercial storage of Fruits and Vegetables and Florist and Nursery Stock", Agricultural Handbook NO.66 US Department of agricultural research services, New York.

36. Roundsa, L., Havensa, C. M., Feinsteinb, Y., Friedmanc, M. and Ravishankar, S. (2013). Concentration-dependent inhibition of Escherichia coli O157:H7 and heterocyclic amines in heated ground beef patties by apple and olive extracts, onion powder and clove bud oil. Meat Science, 94(4): 461-467.

37. Sabo, E. and Zura, Y. D. (2009). "Awareness and effectiveness of vegetable technology information packages by vegetable farmers in Adamawa State, Nigeria". African Journal of Agricultural Research Vol. 4 (2), pp. 065-070.

38. Tafinta, I. Y., Shehu, K., Abdulganiyyu, h., Rabe, A. M. and Usman, A. (2013). Isolation and
Identification of Fungi associated with the Spoilage of Sweet Orange (Citrus sinensis) fruits in Sokoto State. Nigerian Journal of Basic and Applied Science 21(3): 193-196.

39. Tiwari, B. K., Valdramidis, V. P., O’ Donnell, C. P., Muthukumarappan, K., Bourke, P. and Cullen, P. J. (2009). Application of natural antimicrobials for food preservation. Journal of Agricultural and Food Chemistry, 57(14): 59876000 . 